\title{
Effect of Sleep Quality on Blood Glucose Level of Type 2 Diabetes Mellitus Patients in Medan, Indonesia
}

\author{
Rina Amelia ${ }^{1 *}$, Juliandi Harahap ${ }^{1}$, Novita Sari Harahap ${ }^{2}$, Hendri Wijaya ${ }^{3}$, Reni Asmara Ariga ${ }^{4}$, Isti IImiati Fujiati ${ }^{1}$,
} Rusdiana Rusdiana ${ }^{5}$

${ }^{1}$ Department of Community Medicine and Public Health, Faculty of Medicine, Universitas Sumatera Utara, Medan, Indonesia; ${ }^{2}$ Department of Sports Sciences, Faculty of Sport Sciences, Universitas Negeri Medan, Medan, Indonesia; ${ }^{3}$ Department of Paediatrics, Faculty of Medicine, Universitas Sumatera Utara, Medan, Indonesia; ${ }^{4}$ Department of fundamental nursing, Faculty of Nursing, Universitas Sumatera Utara, Medan, Indonesia; ${ }^{5}$ Department of Biochemistry, Faculty of Medicine, Universitas Sumatera Utara, Medan, Indonesia

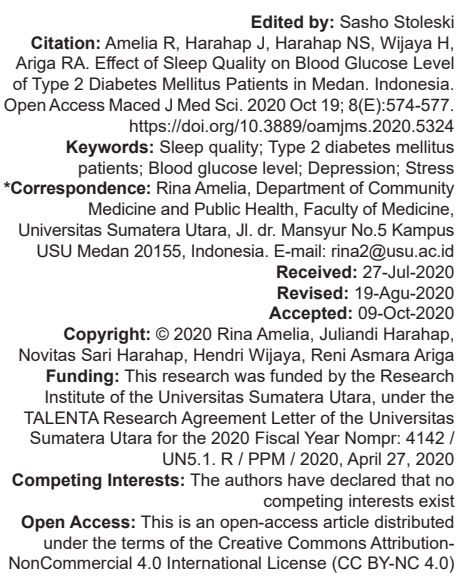

\section{Abstract}

BACKGROUND: Sleep disturbance is one of the problems complained by diabetes mellitus (DM) patients. The decrease in sleep quality has an impact on not controlling blood glucose levels (BGL)

AIM: The aim of the study was to analyze the effect of sleep quality on control BGLs of type 2 DM patients in Medan.

METHODS: This study is analytic with a cross-sectional design. The study population was type 2 DM patients who came to the Medan Labuhan Primary Health Care with a total sample of 83 people, sample collection by consecutive sampling method (inclusion and exclusion criteria). Management data using the SPSS computer program and data analysis using the Chi-square test.

RESULTS: The majority of patients were female (57.8\%), the most age group was above 50 years $(98.8 \%)$, with the highest duration of illnesses being above 5 years $(77.1 \%)$, family history of suffering from DM was mothers with DM $(36.1 \%)$, and mean of BGL was $215 \mathrm{mg} / \mathrm{dl}$. The Chi-square test results showed a significant relationship between sleep quality and BGL of type 2 DM patients in Medan $(p<0.05)$, with an odds ratio of 4.3.

CONCLUSION: Sleep quality affects blood sugar control in type $2 \mathrm{DM}$ patients. The risk of increasing blood suga due to sleep disorders is 4.3 times compared to DM patients who do not experience sleep disorders.

\section{Introduction}

Diabetes mellitus (DM) is a chronic metabolic disorder due to the pancreas not producing enough insulin, or the body cannot use the insulin produced expertly. DM is also caused by insufficient insulin hormone produced by the pancreas to neutralize blood glucose in the body. The hormone insulin function is to process sugars or glucose derived from drinks or food consumed by a person [1], [2].

The liver and tissues regulate the balance between glucose production and use. It is also influenced by the ability of insulin secretion by pancreatic beta cells to produce insulin. When a person lacks sleep, there can be a decrease in glucose tolerance, which causes an increase in glucose levels between $20 \%$ and $30 \%$ [1]. The causes of hormonal changes and sleep disturbances that occur can be caused by the activity of the hypothalamus-pituitary-adrenal and the sympathetic nervous system. Both will stimulate the release of hormones such as cortisol and catecholamines, causing impaired glucose tolerance and insulin resistance related to type 2 diabetes. The existence of sleep disturbances, especially non-eye rapid movement (NREM) for 3 days, can result in a decrease in insulin sensitivity by around $25 \%$ and is one of the risk factors for DM [1].

If the level of blood glucose level (BGL) reaches above 160-180 $\mathrm{mg} / \mathrm{dL}$, glucose will increase secretion in urine. If the glucose level is even higher, the kidneys will remove additional water to thin a large amount of glucose lost; because the kidneys produce excessive amounts of urine, DM sufferers often urinate in large amounts. As a result, they feel excessive thirst, so drink a lot. To compensate for this, sufferers often feel extraordinary hunger, so much to eat. This situation 
can disrupt sleep sufferers at night because they often wake up.

This study aims to analyze the relationship between sleep quality and BGL in type $2 \mathrm{DM}$ patients in Medan Labuhan Primary Health Care (PHC) Medan.

\section{Methods}

This study is an analytic method with a crosssectional approach. The population was typed 2 DM patients in Medan Labuhan PHC who came and controlled regularly.

\section{Study setting}

The research was conducted at the Medan Labuhan PHC, Medan, based on data from the health department province; the Medan Labuan PHC is one of the PHC that has a large number of DM patients, besides that, Medan Labuhan PHC is a fostered area of the Medical Faculty of Universitas Sumatera Utara, making it easier to monitor further patients.

\section{Study population and sampling}

The sample size was determined using the proportion formula (the proportion of the previous study was 0.324 [1]) to obtain a sample size of 83 people. The sample was taken using consecutive sampling, which is a sampling technique based on inclusion and exclusion criteria that have been determined. Inclusion criteria: Willing to be a research respondent by signing informed consent, the exclusion criteria: Patient consumed medication to help sleep, history of head trauma, have a history of psychiatric disorders known from interviews and treatment history that is seen through medical records patient participation in this study was voluntary, each patient who agreed to participate had signed informed consent. Before the study, this study received ethical clearance from the Research Ethics Commission of the Universitas Sumatera Utara.

\section{Study tool}

Research data are primary data. For sleep quality, data obtained through interviews using the Pittsburgh sleep quality index (PSQI) questionnaire, and to measure the BGL (ad random) with a portable blood glucose check. The PSQI questionnaire has seven components: Sleep latency, sleep disturbances, the habit of using drugs to help sleep, sleep efficiency, sleep duration, a disturbance that is often experienced during the day, and subjective sleep quality. PSQI has validity and reliability values of 0.89 and 0.885 . This PSQI scale assessment uses a scoring key for the entire patient range of $0-3$. All scores were calculated and yielded a global overall year score ranging from 0 to 21. An overall score of 5 or more indicates poor sleep quality and vice versa. In PSQI, the seven components that are owned are scattered in 9 questions [3].

\section{Statistical method}

Data were processed using SPSS to determine the relationship between sleep quality and the BGL Chisquare test was used. Data are presented in the form of a frequency distribution table.

\section{Results}

Based on Table 1 shows that DM patients were more female, namely $57.8 \%$, the age group above 50 years had the highest percentage of $98.8 \%$. This study showed that patients' sufferers from DM for more than 5 years $(77.1 \%)$, most of the patients have found that the genetic factors of DM came from the biological mother of the patient, which is as much as $36.1 \%$.

Table 1: Characteristic of type 2 DM patients

\begin{tabular}{|c|c|c|}
\hline Characteristic & Frequency (person) $n=83$ & Percentage \\
\hline \multicolumn{3}{|l|}{ Gender } \\
\hline Male & 35 & 42.2 \\
\hline Female & 48 & 57.8 \\
\hline \multicolumn{3}{|l|}{ Age } \\
\hline$<50$ years & 1 & 1.2 \\
\hline$\geq 50$ years & 82 & 98.8 \\
\hline \multicolumn{3}{|l|}{ Duration of illness } \\
\hline syears & 19 & 22.9 \\
\hline$>5$ years & 64 & 77.1 \\
\hline \multicolumn{3}{|l|}{ Family history } \\
\hline Father & 29 & 34.9 \\
\hline Mother & 30 & 36.1 \\
\hline None & 24 & 28.9 \\
\hline \multicolumn{3}{|l|}{ Drug consumption } \\
\hline Glibenclamide & 29 & 34.9 \\
\hline Glimepiride & 21 & 25.3 \\
\hline Insulin & 11 & 13.3 \\
\hline Metformin & 22 & 26.5 \\
\hline \multicolumn{3}{|l|}{ BMI } \\
\hline Normal & 9 & 10.8 \\
\hline Obese & 46 & 55.41 \\
\hline Pre-obese & 28 & 33.7 \\
\hline \multicolumn{3}{|l|}{$\mathrm{BGL}(\mathrm{mg} / \mathrm{dl})$} \\
\hline Poor control (> $180 \mathrm{mg} / \mathrm{dl})$ & 44 & 53.0 \\
\hline Good control (< $180 \mathrm{mg} / \mathrm{dl})$ & 39 & 47.0 \\
\hline \multicolumn{3}{|l|}{ Sleep quality } \\
\hline Poor & 41 & 49.4 \\
\hline Good & 42 & 50.6 \\
\hline
\end{tabular}

Based on the type of treatment given to patients, it is known that the majority of patients took an oral anti-diabetic drug, namely glibenclamide, as many as 29 patients (34.9\%); in the calculation of BMI, known the majority of the patients were pre-obese as 
many as $33.7 \%$. The results of $\mathrm{BSL}$ known that most patients have poor control (BGL> $180 \mathrm{mg} / \mathrm{dl}$ ) as many as 44 people $(53.0 \%)$, whereas in DM patients with normal BGL (good control) are $<180 \mathrm{mg} / \mathrm{dl}$ as many as 39 people (47.0\%) [4]. Whereas, the assessment of sleep quality in DM patients in this study showed that $49.4 \%$ of patients had poor sleep quality, while $50.6 \%$ of them had good sleep quality.

Table 2 showed that among subjects with poor sleep quality as many as 29 subjects $(70,7 \%)$ had high BGL and 15 subjects $(35,7 \%)$ had normal BGL. The Chi-square test results showed a correlation between the quality of sleep with BGL in type 2 DM patients. This study odds ratio value was 4.3 , meaning that patients with sleep problems had a risk of increasing blood sugar by 4.3 times compared to DM patients whose sleep had no problems.

Table 2: Relationship between sleep quality and blood sugar levels

\begin{tabular}{llllll}
\hline Quality of sleep & \multicolumn{2}{l}{ Blood sugar level } & Total & p & OR \\
\cline { 2 - 4 } & Poor control & Good control & & & \\
\hline Good & $15(35.7 \%)$ & $27(64.3 \%)$ & 42 & 0,001 & 4.3 \\
Poor & $29(77.7 \%)$ & $12(29.3 \%)$ & 41 & & \\
\hline OR: Odds ratio. & & & & &
\end{tabular}

\section{Discussion}

Based on this study, the majority of diabetic patients have poor control (BGL> $180 \mathrm{mg} / \mathrm{dL}$ ) [4]. This study is similar to previous studies, which found the highest number of respondents in high BGL, about $71.7 \%$ [5].

According to the American Diabetic Association (2019), many factors can affect a patient's blood sugar control, and a thriving medical evaluation depends on beneficial interactions between the patient and the care team. One crucial factor is the patient's psychological problems, such as stress or depression experienced by patients who are not appropriately resolved, can affect their BGL [4], [6], [7], [8].

In this study, most of the type 2 DM patients in Medan Labuhan PHC had and poor sleep quality; this condition can be caused by the patient experiencing urinary disorders at night, discomfort due to pain or tingling felt, emotions, and worry about excessive disease, so that disrupt sleep quality and have an impact on BGL [9]. Sleep quality includes quantitative and qualitative aspects of sleep, such as length of sleep, the time needed to fall asleep, frequency of awakening, and subjective aspects such as depth and severity of sleep. Patients with DM generally complain of frequent urination, feeling thirsty, feeling hungry, itching on the skin, and other physical complaints such as nausea and dizziness. Clinical symptoms at night, and diabetic patients, this can certainly interfere with sleep. The occurrence of sleep disorders will have an impact on increasing the frequency of awakening, difficulty falling asleep again, and sleep dissatisfaction, which ultimately results in a decrease in sleep quality. Furthermore, the lack of sleep over a long period can cause other illnesses or worsen the existing disease and affect the healing process's length. Based on the results, patients with type $2 \mathrm{DM}$ in Medan Labuhan PHC have a long sleep time but a short sleep, so that sleep efficiency is poor [9], [10], [11], [12], [13], [14], [15].

Good quality sleep is needed to help the formation of new body cells, repair damaged body cells, give the body time to rest, and maintain the body's metabolic and biochemical balance. Sleep loss can affect the involvement of hormones in the regulation of appetite, after sleep restriction, the level of leptin, which is a factor that makes a person become full, decreases, and the level of ghrelin, which is a stimulation of appetite, increases. Being a little sleep time also increases a person's chance to eat. Hence, losing sleep will increase appetite and increase food intake, which can lead to obesity and increased BGL [8], [9], [10], [11], [13].

If the sugar level is not controlled or left untreated, these chronic symptoms will arise, and this will cause the sufferer to feel uncomfortable and have difficulty sleeping. Complaints of pain in the extremities are a common complaint in people with DM, especially in chronic patients, especially with glucose control that is not good. The sensation that can be felt varies as a burning sensation, punctured. This makes it difficult for sufferers to sleep. Physical discomfort is a major cause of difficulty sleeping or waking up at night [15], [12]. Psychosocial factors also play a role in the quality of sleep. Sleep disorders are reported by $90 \%$ of individuals who experience stress, anxiety, and depression, and it happens to someone who has an illness. A person can experience emotional stress due to illness. Therefore, a person's emotions can affect the ability to sleep. Emotional stress causes a person to become tense and often leads to frustration when not sleeping. Stress also causes a person to try too hard to fall asleep, often wake up during the sleep cycle, or sleep too much. Continued stress can cause poor sleep habits. Stress can change a person's sleep patterns over time. During psychological stress, the time needed to start sleep increases [14], [16].

Disease sufferers who are at risk for anxiety are those who are afraid and worried about the disease, are isolated from family and relatives, and are not familiar with the environment. Anxiety causes the time needed to start to sleep very long, the stage of NREM sleep and rapid eye movement sleep decreases, and patients wake up more often at night. Depression is a disease that affects the psychological effects. Someone who has been depressed will experience sleep disorders where the characteristic of someone affected by the syndrome is always challenging to sleep [6], [13]. 
This study is the same as research conducted by Lei Zhang on sleep quality and the factors that affect sleep disorders showed that while undergoing treatment in the hospital, the number of patients with poor sleep quality was $45.6 \%$ and after undergoing treatment of patients whose sleep quality decreased was as much as $57.4 \%$. The factors related to the quality of sleep of patients during the hospital include anxiety related to the disease, discomfort, and frequent urination at night [6].

\section{Conclusion}

Sleep disturbances can lead to uncontrolled blood sugar in patients with type $2 \mathrm{DM}$, the risk of increasing BGL is 4.3 times greater; by overcoming the problem of sleep disorders will help patients to rest well and have an impact on better sugar control so that it will improve their quality of life.

\section{References}

1. SpiegelK, LeproultR, VanCauterE.Impactofsleepdebtonmetabolic and endocrine function. Lancet. 1999;354(9188):1435-9. https:// doi.org/10.1016/s0140-6736(99)01376-8

PMid: 10543671

2. Gustimigo ZP. Kualitas tidur penderita diabetes melitus. J Majority. 2015;4(8):133-8.

3. Arifin Z. Analisis Hubungan Kualitas Tidur Dengan Kadar Glukosa Darah Pasien Diabetes Mellitus Tipe 2 di Rumah Sakit Umum Propinsi Nusa Tenggara Barat. Jakarta: Universitas Indonesia; 2011. https://doi.org/10.35892/jikd.v15i1.326

4. American Diabetes Association. Disclosures: Standards of Medical Care in Diabetes. United States: American Diabetes Association; 2019.

5. Amelia R, Damanik HA, Lindarto D, Mutiara E. The correlation between the level of $\mathrm{HbA} 1 \mathrm{c}$ with total serum cholesterol of uncontrolled Type 2 diabetes mellitus patients in Binjai, Sumatera Utara. Adv Sci Lett. 2017;23(4):3610-3. https://doi. org/10.1166/asl.2017.9193

6. Amelia R, Yunanda Y. Relationship between depression and glycemic control among patients with Type 2 diabetes in Medan. IOP Conf Ser Earth Environ Sci. 2018;125(1):012170. https:// doi.org/10.1088/1755-1315/125/1/012170

7. Depkes RI. Pedoman Pengendalian Diabetes Melitus Dan Penyakit Metabolik. Jakarta: Depkes Rl; 2011.

8. Siddiqui MA, Khan MF, Carline TE. Gender differences in living with diabetes mellitus. Mater Sociomed. 2013;25(2):140. https:// doi.org/10.5455/msm.2013.25.140-142

PMid:24082841

9. Richardo B, Pangemanan D, Mayulu N. Analisis Faktor Resiko Penyebab Terjadinya Diabetes Mellitus Tipe 2 Pada Wanita Usia Produktif di Puskesmas Wawunasa. Indonesia: Universitas Sam Ratulangi; 2014. https://doi.org/10.35790/ebm.2.2.2014.4554

10. Romadoni S, Septiawan CD. Kualitas tidur dengan kadar glukosa darah pasien diabetes mellitus Tipe 2 di rumah sakit $X$ Palembang. Masker Med. 2016;4(2):273-82.

11. Sivertsen B, Pallesen S, Sand L, Hysing M. Sleep and body mass index in adolescence: Results from a large population-based study of Norwegian adolescents aged 16 to 19 years. BMC Pediatr. 2014;14(1):204. https://doi. org/10.1186/1471-2431-14-204

12. Björkelund C, Bondyr-Carlsson D, Lapidus L, Lissner L, Månsson J, Skoog I, et al. Sleep disturbances in midlife unrelated to 32-year diabetes incidence: The prospective population study of women in Gothenburg. Diabetes Care. 2005;28(11):2739-44. https://doi.org/10.2337/diacare.28.11.2739 PMid:16249549

13. Kurnia J, Mulyadi N, Rottie J. Hubungan kualitas tidur dengan kadar glukosa darah puasa pada pasien diabetes melitus Tipe 2 di rumah sakit pancaran kasih gmim Manado. J Keperawatan. 2017;5(1):1-10. https://doi.org/10.35892/jikd.v15i1.326

14. Soewondo P, Pramono LA. Prevalence, characteristics, and predictors of pre-diabetes in Indonesia. Med $\mathrm{J}$ Indones. 2011;20(4):283-94. https://doi.org/10.13181/mji.v20i4.465

15. Najatullah IW. Hubungan kualitas tidur dengan kontrol glukosa darah pasien DM Tipe 2 di Klinik spesialis perawatan luka, stoma, dan inkontinensia "KITAMURA" pontianak tahun 2015. Indonesia: Program Studi IImu Keperawatan Fakultas Kedokteran Universitas Tanjungpura Pontianak; 2015. https:// doi.org/10.7454/psr.v1i3.3490

16. Lei Z, Qiongjing Y, Qiuli WU, Sabrina K, Xiaojing L, Changli W. Sleep quality and sleep disturbing factors of inpatients in a Chinese general hospital. J Clin Nurs. 2009;18(17):2521-9. https://doi.org/10.1111/j.1365-2702.2009.02846.x PMid:19694879 